\title{
A global scientific literature of research on water quality indices: trends, biases and future directions
}

\author{
A literatura científica global de pesquisa sobre os índices de qualidade da água: \\ tendências, vieses e direçóes futuras
}

\author{
Maria Tereza Ribeiro Alves ${ }^{1}$, Fabrício Barreto Teresa ${ }^{2}$ and João Carlos Nabout ${ }^{1}$ \\ ${ }^{1}$ Unidade Universitária de Ciências Exatas e Tecnológica - UnUCET, \\ Universidade Estadual de Goiás - UEG, CEP 75.132-903, Anápolis, GO, Brazil \\ e-mail: terezaengenhariafl@hotmail.com; joao.nabout@ueg.br \\ ${ }^{2}$ Unidade Universitária Porangatu, Universidade Estadual de Goiás - UEG, \\ CEP 76550-000, Porangatu, GO, Brazil \\ e-mail: fabricioteresa@yahoo.com.br
}

\begin{abstract}
Aim: Water quality has been the subject of many recent studies, moreover, the physical, chemical and biological parameters of water are used to investigate water quality and can be combined into a single index, the Water Quality Index (WQI), for use by water resource managers and the general public. The aim of this study was to use scientometrics to evaluate how water quality has been addressed in the international scientific literature. Method: For the quantitative analysis of the publications on WQI, we used the search database SCOPUS (http://www.scopus.com). The search was performed using the words "QUALIT* WATER* INDEX" in papers published in all databases (through 2011). Results: We found 554 articles that dealt with the use of WQI the number of publications has increased significantly over the last 20 years. India had the most studies, with 177 articles, followed by China, Brazil and the United States. These four countries together published $57 \%$ of studies on WQI. We generated 15 linear models to explain the number of publication by study sit (country). According to the Akaike Information Criterion (AIC), the best model to explain the number of publications by country was the model that combined Sanitation and Public Supply. Conclusion: Finally, this paper presents the state of scientific literature on WQI and demonstrates the growing interest of the scientific community in this issue, which is certainly due to the importance of the quantity and quality of water for human supply, economics, health and the conservation of water resources.
\end{abstract}

Keywords: scientometrics, river, stream, NSF, sanitation, water supply.

Resumo: Objetivo: A qualidade da água tem sido objeto de muitos estudos recentes, além disso, os parâmetros físicos, químicos e biológicos da água são usados para investigar a qualidade da água e podem ser combinados em um único índice, um Índice de Qualidade de Água (IQA), para uso de recursos hídricos gestores e público em geral. O objetivo deste estudo foi utilizar a cienciometria para avaliar como a qualidade da água tem sido abordada na literatura científica internacional. Método: Para a análise quantitativa das publicaçôes sobre IQA, foi utilizada a pesquisa de banco de dados SCOPUS (http://www.scopus.com). A pesquisa foi realizada utilizando as palavras "QUALIT* WATER* INDEX*", em artigos publicados em todos os bancos de dados (até 2011). Resultado: Encontramos 554 artigos que tratavam do uso de IQA, e o número de publicaçóes aumentou significativamente ao longo dos últimos 20 anos. A Índia teve o maior número de estudos, com 177 artigos, seguidos por China, Brasil e Estados Unidos. Esses quatro países juntos publicados 57\% dos estudos sobre IQA. Geramos 15 modelos lineares para explicar o número de publicação de estudo por país. De acordo com o Critério de Informação de Akaike (AIC), o melhor modelo para explicar o número de publicaçóes por país foi o modelo que combinou Saneamento e Abastecimento Público. Discussão: Finalmente, este trabalho apresenta o estado da literatura científica sobre WQIs e demonstra o crescente interesse da comunidade científica nesta questão, que é, certamente, devido à importância da quantidade e da qualidade da água para abastecimento humano, a economia, a saúde e a conservação dos recursos hídricos.

Palavras-chave: cienciometria, rio, córrego, NSF, saneamento, abastecimento de água. 


\section{Introduction}

Water quality has been the subject of many recent studies (Magesh and Chandrasekar, 2013; Singh et al., 2011; Pandey et al., 2012), mainly because of the increasing challenges of water scarcity and poor water distribution. The quantity and quality of water have been causes for concern since ancient times. For example, the Egyptians built staggered dams along the Nile River to ensure a reliable water supply, and they even understood the potential for waterborne disease transmission, as evidenced by their use of filtering processes (Dorevitch et al., 2011). Currently, water quality has gained increased research interest due to anthropogenic pressure on water bodies (Terrado et al., 2010; Espejo et al., 2012; Pfister et al., 2011).

Many countries are beginning to experience difficulties with water supply because of increased demand for water by agriculture and industry, coupled with poor management or a lack of management of water resources (Kharraz et al., 2012; Montesinos et al., 2011; Pfister et al., 2011). Moreover, the pollution from industrial activities, urban areas and non-point sources, such as agriculture and cattle farms has promoted deterioration in water quality farms (UNEP, 2008). In light of the increasing concerns over water quality, increasing research has focused on this topic (Kumar and Singh, 2005; Passiora, 2006; Mojid et al., 2012).

Water quality degradation can be associated with changes in physico-chemical parameters, such as sediment load, nutrient concentrations, temperature, dissolved oxygen levels, $\mathrm{pH}$ (Swamee and Tyagi, 2007) and biological indicators at the individual, population and community levels (Abbasi and Abbasi, 2012). A Water Quality Index (WQI) (Lumb et al., 2011; Bordalo et al., 2001) offers a way to evaluate water quality from multiple parameters and simplify their interpretation. WQI were created in order to compare water quality at different locations and over time (Espejo et al., 2012).

The first attempt to develop a WQI was in Germany in 1948, when researchers found a correlation between pollution levels and certain communities of organisms (fish, benthic organisms and plants). Later, the German researcher Horton developed Horton's Index in 1965. This WQI was used in a program to reduce pollution and to inform the population (Lumb et al., 2011). An important and widely used WQI was developed by the National Sanitation Foundation of the United States
(NSF) in 1970, based on a survey that determined the nine most important parameters driving overall water quality (Lumb et al., 2011). Therefore, the WQI are not recent, and have been widely used in various parts of the world to assess water quality (Abbasi and Abbasi, 2012).

At the present time, new indices have been developed and implemented in a range of countries and by using different parameters (e.g. Clavel et al., 2013; Rubio-Arias et al., 2013). While some questions as which WQI's are more commonly used, their pros and cons, have been studied before (Lumb et al., 2011), other related to the patterns of scientific production on this theme have not been evaluated, such as, what is the trend of the number of papers about WQI; what kind of environment has been studied; why some countries have more papers about WQI than others. Certainly these and other questions can only be answered by performing scientometric analyzes. Scientometric techniques have been used successfully for analyses of research on global climate change (Nabout et al., 2012), biodiversity and ecosystem functioning (Caliman et al., 2010), biotic integrity (Ruaro and Gubiani, 2013), and taxonomic groups (Padial et al., 2008; Carneiro et al., 2008) and may offer insight into WQI, as well.

The objective of this study was to investigate the scientific literature on WQI using scientometrics techniques to identify trends and biases. Thus, we sought to i) describe trends in the number of papers on WQI, ii) quantify the countries and journals where studies were conducted and published, respectively, iii) describe the type of water use and types of aquatic environments where studies have been conducted, iv) quantify which WQI's were used and v) investigate which factors determine the number of papers by country. More specifically in relation to this last question, we tested if socioeconomic variables as sanitation, public supply, human development index and gross domestic product may predict the country's scientific production on WQI. We expected that countries with more papers would be those with the lowest levels of sanitation and water supply because they have greater need for studies on water quality and that countries with more published articles would have higher HDI and GDP because of increased investment in research (Nabout et al., 2010).

\section{Material and Methods}

For the quantitative analysis of the publications on WQI, we used the search database SCOPUS (http://www.scopus.com). The search was performed 
using the words "QUALIT* WATER* INDEX*" in papers published in all databases (until 2011). We used this term to search keywords, titles and abstracts. The asterisk ensured that the terms were found no matter what suffix may have been used. The search began in 1974, the year that the number of papers indexed in the SCOPUS database started to increase.

For each paper, we obtained the following data, if possible: a) the year of publication, b) the country or region where the research was conducted, c) the type of aquatic environment studied, d) the publishing journal, e) the type of water use studied, f) the water quality evaluation method, and g) the type of WQI used. For type of aquatic environment $[\mathrm{c}]$, we classified the study sites as aquifer, groundwater, artesian well, river, dam or reservoir, lakes and floodplains. Coastal lakes were also considered lakes. For type of water use [e], the uses were classified as water for extraction and public supply, reused water, water for agriculture (irrigation), water for fish or seafood farming, and Wastewater Treatment Plants (WTP) and Water Treatment Stations (WTS).

In the data analysis, we used descriptive statistics and Pearson's correlation $(P<0.05)$ to assess any trend in the relationship between publication year and the number of papers. To investigate how research on WQI was distributed across countries, we generated multiple regression models. The response variable was the number of papers by country, and the explanatory variables were the percentage of sanitation in the country, percentage of public supply, Human Development Index (HDI) and Gross Domestic Product (GDP). These data were provided by the United Nations (http:// www.un.org/en/, accessed on 08.15.2012).

We generated fifteen models using these four variables. They were compared according to the Akaike Information Criterion (AIC), in which lower AIC values indicate better models (Burhman and Anderson, 2002). To reduce the influence of extreme values, the variables were transformed: the data for sanitation and HDI were transformed using the square root of the arccosine, while the GDP and water supply data were logarithmically transformed.

\section{Results}

We found 554 articles that dealt with the use of WQI's between 1974 and 2011. The first paper on WQI was from 1974, in the United States (Walski and Parker, 1974). The paper proposes a new index for the Nashville River, Tennessee. Since then, the number of publications on this issue has increased significantly $(r=0.71, \mathrm{P}<0.001)$, and in 2011, we found the highest number of publications, with 98 published papers (Figure 1).

Although 250 journals have published studies using WQI, 20 journals published them much more often, with $44 \%$ of all publications. The Indian Journal of Environmental Protection published

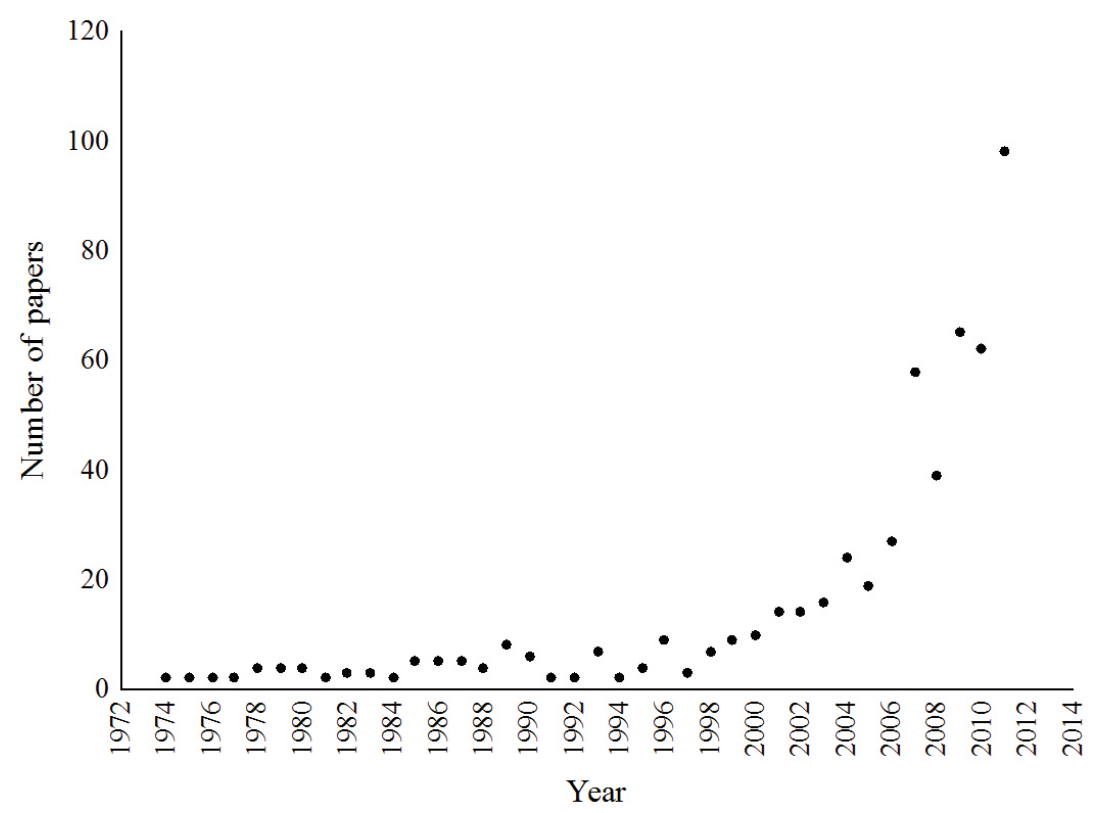

Figure 1. Temporal trend in the number of papers that contained the words "Water* qualit* index*" in the Scopus database. 
the most ( 45 papers), followed by Environmental Monitoring and Assessment (35 papers).

In relation to the types of aquatic environment (were classified 388 papers), rivers and streams represented the large majority of water studied, with 56\% of the studies (Figure 2A). Moreover, all aquatic environments has increased the number of papers on WQI (as evidenced by positive Pearson correlation coefficient) (Figure 2B). In relation to type of water use (were classified 237 papers), water supply to the public was the subject of $76.3 \%$ of the papers, the agricultural supply was examined in $19.8 \%$, water reuse was studied in $13.5 \%$, water from WTP/ WTS was studied in $8.01 \%$, and water used for fish and seafood farming was studied in $5.9 \%$.

Most of the papers used WQI described in literature; only $20 \%$ of the papers proposed new indices for different environments that were developed according to the requirements of each country. Ninety-seven different WQI were identified, with NSF-WQI (23\% of the papers) being the most frequently cited.

In terms of research sites, $84 \%$ of the papers described the location where the study was conducted. India had the most studies, with 177 articles (38\% of the papers), followed by China ( 45 papers or $9.6 \%$ of the total), Brazil (26 papers or $5.5 \%$ of the total) and the United States (21 papers or $4.5 \%$ of the total). These four countries together published $57 \%$ of studies on WQI (Figure 3).

We generated 15 models to explain the number of publication by study site, i.e., the country where the water data were collected. According to the AIC, the best model to explain the number of publications by country was the model that combined Sanitation and Public Supply, followed by the model that combined Sanitation, GDP and HDI (Table 1). It is noteworthy that each of the first five models are considered robust, with an AIC $<2$. Furthermore, our results indicated the sanitation was the most important of the variables, followed by GDP (Table 2). Sanitation was important in explaining the scientific production with negative angular coefficient. In the others words, the countries that have published more papers are those with a lower percentage of sanitation.

\section{Discussion}

As far as we know, this was the first study to assess the trend of the world's scientific literature about WQI. Other scientometric studies have been developed on different subjects, which reinforces the importance of this technique to describe the scientific literature. Among these studies to assess trends in particular research areas highlights studies on population ecology (Lima-Ribeiro et al., 2007), phylogenetic methods (Carvalho et al., 2005), global climate change (Nabout et al., 2012), limnology (Melo et al., 2006; Wishart and Davies, 2002), and phytoplankton (Carneiro et al., 2008). These and other studies are showing an overall steady increase in the output of scientific papers (Nabout et al., 2010). Our WQI scientometric study highlighted the strong temporal increase in the number of papers. This trend can be explained by the concerns over maintaining water resources (Espejo et al., 2012). The issue of water quality has gained increasing research interest globally. For example, the European Water Framework Directive of 2000 implements a mandate to restore degraded water bodies and to regulate activities that involve water through 2015 (Terrado et al., 2010;
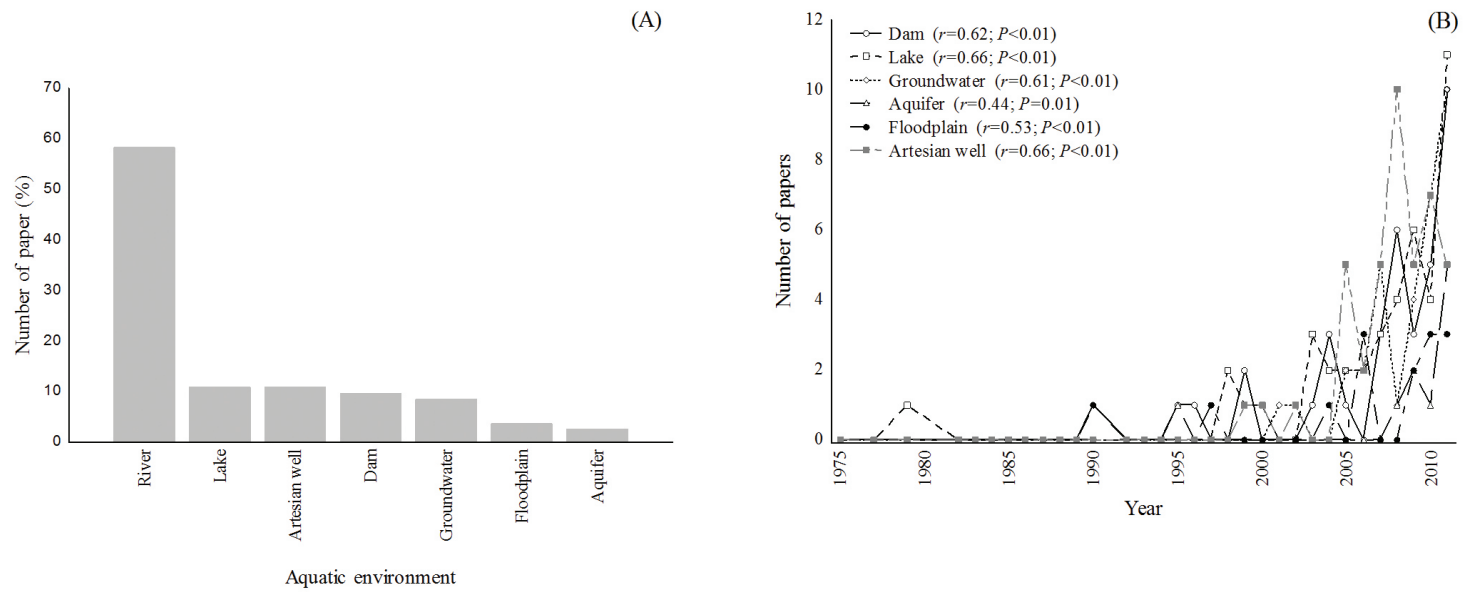

)

Figure 2. Aquatic environment studied (A), and temporal trend in number of paper for each aquatic environment (B). 


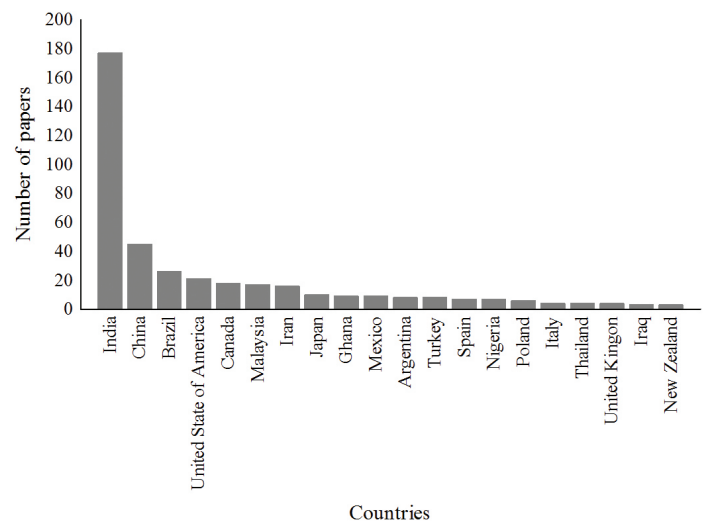

Figure 3. Number of papers published in major countries.

Table 1. Models generated and AIC values for combinations of variables: Sanitation (S), Supply (A), GDP (P) and HDI (I).

\begin{tabular}{lrcc}
\hline \multicolumn{1}{c}{ Models } & \multicolumn{1}{c}{$\mathbf{R}^{2}$} & \multicolumn{1}{c}{ AICc } & Delta AICc \\
\hline S, A & 0.137 & 466.764 & 0 \\
S, P, I & 0.165 & 467.606 & 0.842 \\
S, I & 0.116 & 467.945 & 1.182 \\
S & 0.066 & 468.319 & 1.555 \\
S, P, A & 0.146 & 468.688 & 1.924 \\
S, P & 0.085 & 469.672 & 2.908 \\
S, P, A, I & 0.165 & 470.157 & 3.393 \\
S, P, I & 0.117 & 470.375 & 3.611 \\
I & 0.014 & 471.057 & 4.293 \\
P & $<0.001$ & 471.754 & 4.99 \\
A & $<0.001$ & 471.754 & 4.99 \\
A, I & 0.029 & 472.652 & 5.888 \\
P, I & 0.027 & 472.758 & 5.994 \\
P, A & $<0.001$ & 474.116 & 7.352 \\
P, A, I & 0.046 & 574.23 & 7.466 \\
\hline
\end{tabular}

Table 2. Importance of each variable and the angular coefficient.

\begin{tabular}{lcc}
\hline \multicolumn{1}{c}{ Variable } & Importance & Angular Coefficient \\
\hline Sannity & 0.893 & -56.062 \\
GDP & 0.282 & $<0.001$ \\
Supply & 0.592 & 65.645 \\
HDI & 0.443 & 57.26 \\
\hline
\end{tabular}

Dimitriou et al., 2012; Borja et al., 2013). Many countries such as China and India are concerned because they are either facing water scarcity or the prospect of future scarcity, which would lead to food scarcity and endanger the public water supply (Singh et al., 2011; Wu et al., 2012).

Among the main criticisms to the use of WQI highlight the oversimplification of complex limnological variables to generate a single value (index) in order to classify water quality (excellent, good, fair, poor and bad) (Simóes et al., 2008). In addition, there are the potential for misuse, as WQI's can be used as indicator of water quality for different uses of water (e.g. irrigation, industry, recreation and others) and for different environments, whose referential conditions are expected be different. The generalized use of WQI without consider these variations may generate misinterpretation. These situations usually demand use-specific and sitespecific criteria in order to specifically adapted the WQI to provide the required information on each use and/or environment of interest (Lumb et al., 2011). Nevertheless, these indices have yet been widely accepted, mainly because it can quickly get an understanding of water quality, are easily understandable general public and decision makers, and provide a simplified output from complex multivariate data (Abbasi and Abbasi, 2012).

The journal with the most papers on this issue is the Indian Journal of Environmental Protection, and the high scientific production of this journal may be explained by the high production of articles on this topic in India. We found that 177 articles were published about water in India, focusing on various topics such as coastal environments (Jayachandran and Nandan, 2012); groundwater (Magesh and Chandrasekar, 2013; Singh et al., 2011) and wastewater reuse (Mojid et al., 2012). Rural and isolated locations in India are beginning to face water scarcity, leading to a high dependence on groundwater for public and agricultural supply (Magesh and Chandrasekar, 2013). In the arid and semiarid regions in particular, the dependence of groundwater is increasing due to low rainfall during monsoons, which has caused annual losses in the aquifers (Mojid et al., 2012). This and India's growing need for water management planning may be influencing the high level of interest in this country.

The number of paper from countries such as India, China, Brazil, USA, Canada, Malaysia and Iran can be explained by three variables: public sanitation, water supply and Gross Domestic Product (GDP). Our results suggest that countries with low rates of sanitation and low water quality have more publications. For example, although Brazil has $12 \%$ of all available freshwater in the world, this water does not reach all its inhabitants with a rate of $0.8 \%$ (UN, 2012). This occurs because $73 \%$ of Brazilian waters are concentrated in the Amazon region, while only $5 \%$ of the population occupies that territory (Libânio, 2008). Therefore, only $27 \%$ of the total freshwater of Brazil is available for $95 \%$ of the population. These asymmetrical relations create the need for scientific research on 
water quality in this country, and similar scenarios may occur in countries such as China and India.

The papers described 97 different WQI, and some of them (20\%) suggested new indices. New indices were established for studies of regional issues. For example, Almeida et al. (2012) developed a recreational WQI for lakes in Argentina. Singh et al. (2011) studied the current status of water quality in India and developed a WQI for groundwater and aquifers in that region. Gharibi et al. (2012) created a WQI for the water supply for dairy cattle in Iran. Finally, Varbiró et al. (2012) used limnological variables associated with pollution indices to characterize water bodies in Hungary.

The WQI developed by the National Sanitation Foundation of USA (NSF-WQI) was employed most often. This index has been widely applied in papers from several countries and was the basis for other indices, such as the Oregon WQI (Swamee and Tyagi, 2007). Its parameters are highly independent and can be applied in diverse environments. In addition, it has been widely accepted in many countries, where it has been evaluated and tailored to local conditions (Lumb et al., 2011).

Many studies of water use involve the public supply and agricultural supply. The high production of articles on water for human supply can be explained by changes throughout the twentieth century in sources of human water consumption (Lumb et al., 2011). The pressures exerted by the increasing demand for water lead to needs to manage water and establish limits for certain substances. Therefore, countries have gradually established legislation on water quality. These regulations have led to the need for constant monitoring of water use and a substantial amount of research. Many areas are monitored only for defined periods of time, to monitor and maintain the quality of water bodies (Espejo et al., 2012).

Intense agricultural production depends on irrigation and creates high water demands (Kumar and Singh, 2005). Irrigation has been the solution for many areas that could not produce crops due to the use of an improper hydrological regime for large crops. Through the use of irrigation, unproductive areas can efficiently produce crops every year (Hanjra and Qureshi, 2010). Many countries, including the United States (Paz et al., 2000), use substantial amounts of groundwater to make up to this high demand, which is already causing negative effects, such as water scarcity and groundwater depletion (Singh et al., 2011; Mojid et al., 2012). The number of papers that characterize water quality for irrigation shows that proper management of water in agriculture is an area of interest for researchers.

Rivers and lakes are the most studied environments, as these are the environments where freshwater is more accessible for population. Large rivers that supply many regions such as the Nile River, which passes through ten countries, and the Amazon River, which passes through nine countries in South America (Tundisi, 2008), are of particular interest. These rivers house organisms that are considered more vulnerable to pollution (Espejo et al., 2012). Furthermore, many of these rivers are polluted due to anthropogenic activities (Bhardwaj and Singh, 2011). Rivers have substantial available water but have been greatly affected by human activity, particularly in developing countries (Espejo et al., 2012); these factors explain the large amount of studies on rivers and lakes.

Another variable that could explain the high scientific production of some countries is GDP, as countries with higher GDP can invest more money in research. The use of GDP to explain the scientific production of nations has been applied in other scientometric studies (Fazey et al., 2005; Nabout et al., 2010), which produced similar results to our study. Thus, GDP has a positive relationship with the scientific production of countries. Thus, in contrast to variables such as public water supply and sanitation, which seem be directly related to scientific production on water quality, the correlation with GDP probably is not theme specific, but rather reveals an overall trend of increased scientific production independent of the theme of the research.

\section{Conclusion}

This paper presents the state of scientific literature on WQI and demonstrates the growing interest of the scientific community in this issue, which is certainly due to the importance of the quantity and quality of water for human supply, economics, health and the conservation of water resources. Finally, based on the presented results we can highlight and suggest future directions for the study of WQI: i) Although diversity of indices, most of them have been created considering temperate aquatic environments (e.g. the most used, NSF was created in the United States of America). Therefore, there are few indices considering tropical aquatic environments. Particularly for Brazil, there is a need to develop WQI considering their variety of environments and water availability. Our results 
showed that some very important environments have received little attention, such as floodplains, which are present high biodiversity and unique environmental characteristics;ii) Great part of the criticism regarding the WQI are due to variability of responses among different indices, i.e., under same conditions the indices may show different results (see Abbasi and Abbasi, 2012), hindering decision about water quality. Therefore, a future direction we suggest is a more detailed analysis of the variability of the index, and mainly the search (external or internal) by factors that influence the variability of indices. This understanding will help the researcher to choose the WQI; iii) There is still a lack of studies that focus on the impact of global climate change on aquatic environments (see Nabout et al., 2012). WQI can be excellent indicator to detect changes in water quality considering alteration on climate. For this, we recommend future studies (including experimental studies) that assess the impact of climate change on aquatic environments and the potential use of WQI as an indicator of these impacts.

\section{Acknowledgements}

We acknowledge CAPES for scholarships granted to Maria Tereza Ribeiro Alves. This work was supported by CNPq/MCT/CAPES and FAPEG (project \# 563834/2010-2) and partially supported by CAPES (Auxpe 2036/2013 and Auxpe 1304/2014). FBT was supported by University Research and Scientific Production Support Program (PROBIP/UEG). JCN was supported by $\mathrm{CNPq}$ productivity fellowships.

\section{References}

ABBASI, T. and ABBASI, SA. 2012. Water quality indices. Amsterdam: Elsevier.

ALMEIDA, C., GONZALEZ, SO., MALLEA, M. and GONZALEZ, PA. 2012. Recreational water quality index using chemical, physical and microbiogical parameters. Environmental Science Pollution Research, vol. 19, no. 8, p. 3400-3411. PMid:22528988. http://dx.doi.org/10.1007/s11356-012-0865-5

BHARDWAJ, V. and SINGH, DS. 2011. Surface and groundwater quality characterization of Deoria District, Ganga plain, India. Environmental Earth Sciences, vol. 63, no. 2, p. 383-395. http://dx.doi. org/10.1007/s12665-010-0709-x

BORDALO, AA., NILSUMRANCHI, TW. and CHALERMWAT, K. 2001. Water quality and uses of the Bangpakong river (Eastern Thailand). Water Research, vol. 35, no. 15, p. 3635-3642. http://dx.doi. org/10.1016/S0043-1354(01)00079-3
BORJA, A., ELLIOT, M., HENSIKEN, P. and MARBA, N. 2013. Transitional and coastal water ecological status assessment: advances and challenges resulting from implementing the European Water Framework Directive. Hydrobiologia, vol. 704, no. 1, p. 213-229. http://dx.doi.org/10.1007/s10750-012-1276-9

BURHMAN, KP. and ANDERSON, DR. 2002. Model selection and multimodel inference: a pratical information-theoretic approach. New York: Springer.

CALIMAN, A., PIRES, AF., ESTEVES, FA., BOZELLI, RL. and FARJALLA, VF. 2010. The prominence of and biases in biodiversity and ecosystem functioning research. Biodiversity Conservation, vol. 19, no. 3, p. 651-664. http://dx.doi.org/10.1007/s10531009-9725-0

CARNEIRO, FM., NABOUT, JC. and BINI, JM. 2008. Trends in the scientific literature on phytoplankton. Limnology, vol. 9, no. 2, p. 153-158. http://dx.doi. org/10.1007/s10201-008-0242-8

CARVALHO, P., DINIZ-FILHO, JA. and BINI, LM. 2005. The impact Felsenstein's "Phylogenies and corporative method" on evolutionary biology. Scientometrics, vol. 62, no. 1, p. 53-66. http://dx.doi. org/10.1007/s11192-005-0003-y

Clavel, J., POUlet, N., POrCher, E., BLANCHET, S., GRENOUILLET, G., PAVOINE, S., BITON, A., SEON-MASSIN, N., ARGILLIER, C., DAUFRESNE, M., TEILLAC-DESCHAMPS, P. and JULLIARD, R. 2013. A new freshwater biodiversity indicator based on fish community assemblages. PlosOne, vol. 8, no. 11, p. e80968. PMid:24278356 PMCid:PMC3838364. http:// dx.doi.org/10.1371/journal.pone.0080968

Dimitriou, PD., APOSTOLAKI, ET., PAPAGEOURGIOUS, N., REIZOPOUPOU, S., SIMBOURA, N., ARVANITIALIS, C. and KARAKASSIS, I. 2012. Meta-analysis of a large data set with water Framework Directive indicators and calibration, of a Benthic Quality Index at the family level. Ecological Indicators, vol. 20, p. 101-107. http:// dx.doi.org/10.1016/j.ecolind.2012.02.008

DOREVITCH, S., PANTHI, S., HUANG, Y., LI, H., MICHALEK, AM., PRATAP, P., WROBLEWSKI, M., LIU, L., SCHEFF, PA. and LI, A. 2011. Water ingestion during water recreation. Water Research, vol. 45, no. 5, p. 2020-2028. PMid:21227479. http://dx.doi.org/10.1016/j.watres.2010.12.006

ESPEJO, L., KRESTSCHNER, N., OYARZUN, J., MEZA, F., NÚNEZ, J., MATURANA, H., SOTO, G., OYARZO, P. GARRIDO, M., SUCKEL, F., AMEGAZA, J. and OYARZÚN, R. 2012. Application of water quality indices and analysis of the surface water quality monitoring network in semiarid North - Central, Chile. Environmental Monitoring and Assessment, vol. 1894, no. 9, p. 55715588. 
FAZEY, I., FISCHER, J. and LINDEMAYER, DB. 2005. Who does all the research in conservation biology? Biodiversity and Conservation, vol. 14, no. 4, p. 917-934. http://dx.doi.org/10.1007/s10531-0047849-9

GHARIBI, H., SOWLAT, MH., MAHVI, AH., MAHMOUDZADEH, H., ARABALIBEIK, H., KESHAVARZ, M., KARIMZADEH, N.and HASSANI, G. 2012. Development of a dairy cattle drinking water quality index (DCWQI) based on fuzzy inferences systems. Ecological Indicators, vol. 20, p. 228-237. http://dx.doi.org/10.1016/j. ecolind.2012.02.015

HANJRA, MA. and QURESHI, ME. 2010. Global water crisis and future food security in an era of climate change. Food Policy, vol. 35, no. 5, p. 365-377. http:// dx.doi.org/10.1016/j.foodpol.2010.05.006

JAYACHANDRAN, PR. and NANDAN, SB. 2012. Assessment of trophic change and its probable impact on tropical estuarine environmental (the Kodugallur - Azhikode estuary) India. Mitigation and Adaptation Strategies for Global Change, vol. 17, no. 7, p. 837-847. http://dx.doi.org/10.1007/ s11027-011-9347-1

KHARRAZ, JE., EL-SADEK, A., GHAFFOUR, N. and MINO, E. 2012. Water scarcity and drought in WANA countries. Procedia Engineering, vol. 33, p. 14-29. http://dx.doi.org/10.1016/j. proeng.2012.01.1172

KUMAR, MD. and SINGH, OP. 2005. Virtual water in global food and water policy making: Is there a need for rethinking? Water Resources Management, vol. 19, no. 6, p. 759-789. http://dx.doi.org/10.1007/ s11269-005-3278-0

LIBÂNIO, M. 2008. Fundamentos de qualidade $e$ tratamento de água. 2. ed. Campinas: Átomo. 444 p.

LIMA-RIBEIRO, MS., NABOUT, JC., PINTO, MP., MOURA, IO., COSTA, SS. and RANGEL, TFLVB. 2007. Scientometric analysis in population ecology: importance and scientometric analysis in population ecology: importance and trends of the last 60 years. Acta Scientarium Biological Sciences, vol. 29, no. 1, p. 39-47.

LUMB, A., SHARMA, TC. and BIBEAULT, J-F. 2011. A review of genesis and evolution of Water Quality Index (WQI) and some future direction. Water, Quality, Exposure and Health, vol. 3, no. 1, p. 1124. http://dx.doi.org/10.1007/s12403-011-0040-0

MAGESH, NS. and CHANDRASEKAR, N. 2013. Evaluation of spatial variation in groundwater quality by WQI and GIS technique: a case study of Virudunagar District, Tamil Nadu, India. Arabian Journal of Geosciences, vol. 6, no. 6, p. 1883-1898. http://dx.doi.org/10.1007/s12517-011-0496-z

MELO, AS., BINI, LM. and CARVALHO, P. 2006. Brazilian articles international journals on limnology.
Scientometrics, vol. 67, no. 2, p. 187-199. http:// dx.doi.org/10.1007/s11192-006-0093-1

MOJID, MA., BIWAS, SK. and WYSEURE, GCL. 2012. Interaction effects of irrigation by municipal watershed and inorganic fertilisers on wheat cultivation in Bangladesh. Field Crops Research, vol. 134, p. 200-207. http://dx.doi.org/10.1016/j. fcr.2012.06.010

MONTESINOS, P., CAMACHO, E., CAMPOS, B. and RODRIGUEZ-DIAZ, JA. 2011. Analysis of virtual irrigation water: application to water resources management in a Mediterranean river basin. Water Resource Manage, vol. 25, no. 6, p. 1635-1651. http:// dx.doi.org/10.1007/s11269-010-9765-y

NABOUT, JC., BINI, LM. and DINIZ-FILHO, JAF. 2010. Global literature of fiddler crabs, genus Uca (Decapoda, Ocypodidae): trends and future directions. Iheringia Série Zoologia, vol. 100, no. 4, p. 463-468. http://dx.doi.org/10.1590/S007347212010000400019

NABOUT, JC., CARVALHO, P., PRADO, MV., BORGES, PP., MACHADO, KB., HADAD, RB., MICHELLAN, TS., CUNHA, HF. and SOARES, TN. 2012. Trends and Biases in global climate change literature. Natureza Conservação, vol. 10, no. 1, p. 4551. http://dx.doi.org/10.4322/natcon.2012.008

PADIAL, AA., BINI, LM. and THOMAZ, SM. 2008. The study of aquatic macrophytes in Neotropics: a scientometrical view of the main trends and gaps. Brazilian Journal Biology, vol. 68, no. 4, p. 10511059. PMid:19197475. http://dx.doi.org/10.1590/ S1519-69842008000500012

PANDEY, PK., SOUPIR, ML., HADDAD, M. and ROTHWELL, JJ. 2012. Assessing the impacts of watershed indexes and precipitation on spatial instream E. coli concentrations. Ecological Indicators, vol. 23, p. 641-652. http://dx.doi.org/10.1016/j. ecolind.2012.05.023

PASSIORA, J. 2006. Increasing crop productivity when water is scarce: from breeding to field management. Agricultural, Water Management, vol. 80, p. 176-196. http://dx.doi.org/10.1016/j.agwat.2005.07.012

PAZ, VPS., TEODORO, REF. and MENDONÇA, FC. 2000. Recursos hídricos, agricultura irrigada e meio ambiente. Revista Brasileira de Engenharia Agricola e Ambiental, vol. 4, no. 3, p. 465-473. http://dx.doi. org/10.1590/S1415-43662000000300025

PFISTER, S., BAYNER. P., KOCHLER, A. and HELLWEG, S. 2011. Environmental impacts of water use in global crop production: hotspots and trade-offs with land use. Environmental Science and Technology, vol. 45, no. 13, p. 5761-5768. PMid:21644578. http://dx.doi.org/10.1021/ es1041755

RUARO, R. and GUBIANIA, EA. 2013. A scientometric assessment of 30 years of the Index of Biotic Integrity 
in aquatic ecosystems: applications and main flaws. Ecological Indicators, vol. 29, p. 105-110. http:// dx.doi.org/10.1016/j.ecolind.2012.12.016

RUBIO-ARIAS, H., OCHOA-RIVERO JM., QUINTANA, RM., SAUCEDO-TERAN, R., ORTIZ-DELGADO, RC., REY-BURCIAGA, NI. and ESPINOZA-PRIETO, JR. 2013. Development of a Water Quality Index (WQI) of an artificial aquatic ecosystem in Mexico. Journal of Environmental Protection, vol. 4, no. 11, p. 1296-1306. http:// dx.doi.org/10.4236/jep.2013.411151

SIMÓES, FS., MOREIRA, AN., BISINOTI, MA., GIMENEZ, SMN. and YABE, MJS. 2008. Water quality index as a simple indicator of aquaculture effects on aquatic bodies. Ecological Indicators, vol. 8, no. 5, p. 476-484. http://dx.doi.org/10.1016/j. ecolind.2007.05.002

SINGH, CK., SHASHTRI, S., MUKHERJEE, S., KUNARI, R., AVATAR, R., SINGH, A. and SINGH, RP. 2011. Application of GWQI to asses effect of land use change on groundwater quality in lower Shiwaliks of Punjab: remote sensing and GIS based approach. Water Resource Manage, vol. 25, no. 7, p. 1881-1898. http://dx.doi.org/10.1007/ s11269-011-9779-0

SWAMEE, PK. and TYAGI, A. 2007. Improved method for aggregation of water quality subindices. Environmental Engineering, vol. 133, no. 2, p. 220225. http://dx.doi.org/10.1061/(ASCE)07339372(2007)133:2(220)

TERRADO, M., BORRELL, E., CAMPOS, S., BARCELO, D. and TAULER, R. 2010. Surface- water-quality indices for the analysis of data generated by automated samplings network. Trends in Analytical Chemistry, vol. 29, no. 1, p. 40-52. http://dx.doi. org/10.1016/j.trac.2009.10.001

TUNDISI, JG. 2008. Recursos hídricos no futuro: problemas e soluçóes. Estudos Avançados, vol. 22, no. 63, p. 7-16. http://dx.doi.org/10.1590/S010340142008000200002

United Nations Environment Programme Global Environment Monitoring System (GEMS). Water Programme - UNEP. 2008. Water quality for ecosystem and human health. 2nd ed. Canada.

VARBIRÓ, G., BORICS, G., CSANYI, B., FEHER, G., GRIGORSZHEY, I., KISS, KT., TOTH, A. and ÁCS, E. 2012. Improvement of the ecological water qualification system of rivers based on the first results of the Hungarian phytobenthos surveillance monitoring. Hybrobiologia, vol. 695, no. 1, p. $125-$ 135. http://dx.doi.org/10.1007/s10750-012-1120-2

WALSKI, TM. and PARKER, LF. 1974. Consumers water quality index. ASCE Journal Environmental Engineering Division, vol. 100, no. 3, p. 593-611.

WISHART, MJ. and DAVIES, BR. 2002. Collaboration, conservation and the changing face of limnology. Aquatic Conservation Marine and Freshwater Ecosystems, vol. 12, no. 5, p. 567-575. http://dx.doi. org/10.1002/aqc.507

WU, J., ZENG, H., YU, H., MA, L., XU, L. and QIN, B. 2012. Water and sediment quality in lakes along the middle and lower reaches of the Yangtze river, China. Water Resour Manage, vol. 26, no. 12, p. 3601-3618. http://dx.doi.org/10.1007/s1 1269-012-0093-2 